\title{
THE ROLE OF THYROID HORMONE STATUS IN ABNORMAL UTERINE BLEEDING
}

\author{
Lissiamma George ${ }^{1}$, K. J. Jacob², Swathi B. Shankar ${ }^{3}$ \\ ${ }^{1}$ Additional Professor, Department of Obstetrics and Gynaecology, Government Medical College, Thrissur. \\ 2 Professor, Department of Obstetrics and Gynaecology, Government Medical College, Thrissur. \\ ${ }^{3}$ Senior Resident, Department of Obstetrics and Gynaecology, Government Medical College, Thrissur.
}

\section{ABSTRACT}

\section{BACKGROUND}

Abnormal uterine bleeding can be defined as any bleeding from the genital tract, which is a deviation from the normal in frequency, cyclicity or quantity. The differential diagnosis of abnormal uterine bleeding includes organic causes that may be subdivided into reproductive tract disease, iatrogenic causes and systemic disease. Thyroid dysfunction is one of the causes included in the systemic diseases.

This study was done to know the prevalence of thyroid dysfunction in women presenting with abnormal uterine bleeding.

\section{MATERIALS AND METHODS}

227 women attending gynaecology outpatient department in Government Medical College, Thrissur, with abnormal uterine bleeding in pubertal to pre-menopausal age group were included in this study after excluding structural and endometrial pathology by clinical examination, ultrasound and endometrial sampling. These women were tested for their thyroid function by FT3, FT4 and TSH estimation in the serum. Patients who were on hormonal treatment, intrauterine contraceptive device users and had bleeding disorders were excluded from the study. Pattern of bleeding was also assessed in the study population. Patients diagnosed with thyroid dysfunction were treated and followed up for the response.

\section{RESULTS}

Out of the 227 patients, the majority of the study population belonged to the age group of 41 - 50 years (43.6\%); $21.9 \%$ of the study population showed thyroid dysfunction. Of this $19.7 \%$ had hypothyroidism, out of which $12.3 \%$ were subclinical hypothyroid and $7.5 \%$ were overt hypothyroid; about $2.2 \%$ were hyperthyroid. Majority of the hypothyroid patients had menorrhagia and majority of the hyperthyroid patients had oligomenorrhoea.

\section{CONCLUSION}

Thyroid hormones play a vital role in menstrual bleeding. Identifying and correction of the thyroid status has shown to improve the symptoms in women presenting with heavy menstrual bleeding and improve the quality of life.

\section{KEYWORDS}

Abnormal Uterine Bleeding, Thyroid Dysfunction, Hypothyroidism, Hyperthyroidism, Menorrhagia, Menstrual Disorders, Subclinical Hypothyroidism.

HOW TO CITE THIS ARTICLE: George L, Jacob KJ, Shankar SB. The role of thyroid hormone status in abnormal uterine bleeding. J. Evolution Med. Dent. Sci. 2017;6(76):5448-5451, DOI: 10.14260/Jemds/2017/1182

\section{BACKGROUND}

Abnormal uterine bleeding can be defined as any bleeding from the genital tract, which is a deviation from the normal in frequency, cyclicity or quantity. It accounts for $30 \%-40 \%$ of the cases in the outpatient clinic.

The causes of abnormal uterine bleeding include a wide spectrum of diseases of the reproductive system and nongynaecologic causes as well. ${ }^{1}$ Endocrine cause is one of the important cause for abnormal uterine bleeding in the reproductive age group. ${ }^{2}$ Among the endocrine causes after the pituitary, thyroid is probably the most important. ${ }^{3}$ Both hypothyroidism and hyperthyroidism may be associated with abnormal bleeding.

Financial or Other, Competing Interest: None.

Submission 09-07-2017, Peer Review 07-09-2017,

Acceptance 13-09-2017, Published 21-09-2017.

Corresponding Author:

Dr. K. J. Jacob,

Professor,

Department of Obstetrics and Gynaecology,

Government Medical College,

Thrissur.

E-mail: kjjacobhod@gmail.com

DOI: $10.14260 /$ jemds $/ 2017 / 1182$
Thyroid deficiency causes a change in the rhythm of the oestrus cycle resulting in lengthening or irregularity.4 Oligomenorrhoea and menorrhagia are the most frequently seen menstrual disturbances in hypothyroidism. The menorrhagia is probably the result of breakthrough bleeding associated with anovulation, which leads to deficient LH and excess oestrogen. ${ }^{5}$ Defects in clotting factors (such as decreased levels of factors VII, VIII, IX and XI) that occur in hypothyroidism may also contribute to polymenorrhoea and menorrhagia. Hyperthyroidism can result in oligomenorrhoea or amenorrhea. ${ }^{6}$ Biochemical and hormonal abnormalities, nutritional disturbances and emotional upheavals that are commonly associated with hyperthyroidism may, individually or in combination, be the cause of the menstrual disturbances.

Replacement with synthetic levothyroxine (LT4) is the mainstay of therapy and provided that there is an intact hypothalamic-pituitary-thyroid axis. The menorrhagia associated with hypothyroidism responds promptly to thyroid replacement, as thyroxine has a direct effect on the spiral arterioles and on haemostasis at menstruation. ${ }^{7}$ Thus, estimation of thyroid hormones in serum in woman presenting with abnormal uterine bleeding and adequate 
treatment after diagnosis can prevent unnecessary surgical interventions.

This study was conducted to find out the prevalence of thyroid dysfunction in woman with abnormal uterine bleeding in the reproductive age group, so that by adequate treatment of the thyroid dysfunction there can be improvement in the quality of life.

\section{MATERIALS AND METHODS}

The present study has been carried out at Obstetrics and Gynaecology outpatient department of Government Medical College, Thrissur. The study is a descriptive study and was carried out after IRC approval and consent from the patient. The study consisted of 227 patients in the reproductive age group coming to OPD with complaints of abnormal uterine bleeding from February 2014 to January 2015. Woman with structural pathology, endometrial pathologies, chronic liver disease, bleeding disorders, and IUCD users on drugs like anticoagulants and antidepressants and with carcinoma thyroid were excluded from the study.

\section{Procedure}

The patients coming to Gynaecology OPD with complaints of abnormal uterine bleeding were given the proforma. A detailed history was obtained with special relevance to age and bleeding pattern. A thorough clinical examination including general physical examination with special reference to thyroid dysfunction, neck examination, gynaecological and systemic examination was carried out.

All these patients were subjected to routine investigations like haemoglobin percentage, blood counts, urine examination, prothrombin time (to rule out coagulation defects), peripheral smear and random blood sugar levels. Cervical smears were taken and transabdominal/ transvaginal ultrasound was done to rule out pelvic pathology. Then all patients were subjected for Free Triiodothyronine levels (FT3), Free Thyroxine levels (FT4) and TSH estimation in their sera.

\section{Patients were then Grouped into 4 Categories}

- Euthyroid.

- Subclinical hypothyroid- where TSH is increased and FT3, FT4 is normal.

- Overt Hypothyroid- where TSH is high, FT3 and FT4decreased.

- Hyperthyroid.

Patients found to have thyroid dysfunction were accordingly treated and reassessed for improvement in symptoms. As a part of the investigation, fractional curettage was also done and the patient was accordingly treated.

\section{RESULTS}

\begin{tabular}{|c|c|c|}
\hline Age & Number & Percent \\
\hline$<20$ & 10 & 4.4 \\
\hline $21-30$ & 22 & 9.7 \\
\hline $31-40$ & 75 & 33.0 \\
\hline $41-50$ & 99 & 43.6 \\
\hline$>50$ & 21 & 9.3 \\
\hline \multicolumn{2}{|c|}{ Table 1. Distribution according to Age } \\
\hline
\end{tabular}

The above table shows that the majority of the study population belong to the age group of $41-50$ years (43.6\%). The cases of puberty menorrhagia constitute about $4.4 \%$ of the study population.

\begin{tabular}{|c|c|c|}
\hline Parity & Number & Percent \\
\hline Unmarried & 18 & 7.9 \\
\hline Nulliparous & 8 & 3.5 \\
\hline Para 1 & 89 & 39.2 \\
\hline Para 2 & 98 & 43.2 \\
\hline Para 3 or more & 14 & 6.2 \\
\hline \multicolumn{2}{|c|}{ Table 2. Distribution according to Parity }
\end{tabular}

In this study population, parity of the patients ranged from nulliparous to parity 3 or more. Majority of the patients belonged to para $2(43.2 \%)$.

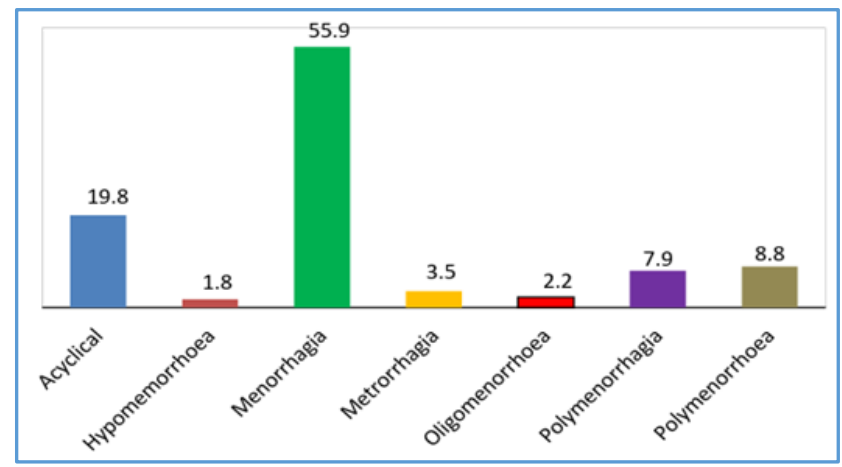

Figure 1. Distribution according to Menstrual Complaints

Menorrhagia was the most common symptom in 127 patients $(55.9 \%)$, followed by acyclical bleeding in 45 patients $(19.8 \%)$ and polymenorrhoea in 20 patients (8.8\%).

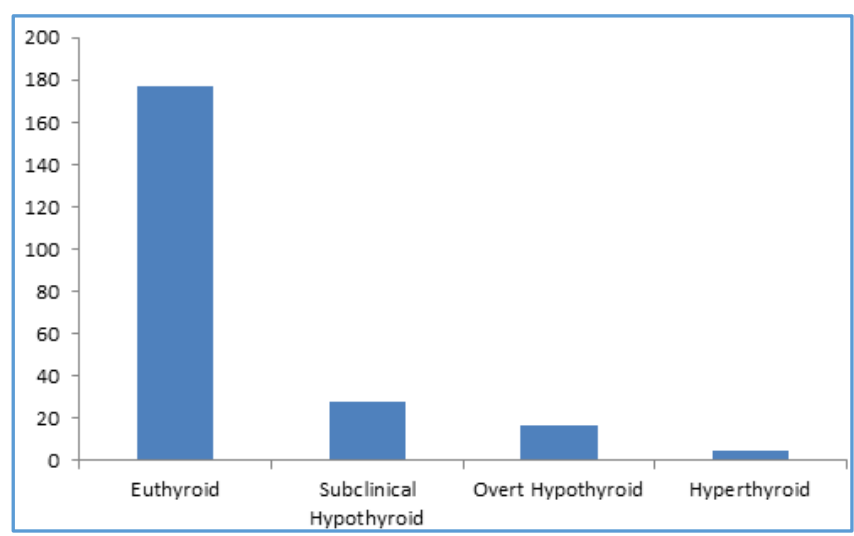

Figure 2. Distribution according to Thyroid Status

Out of 227 patients 45 (19.7\%) had hypothyroidism, out of which $28(12.3 \%)$ were subclinical hypothyroid and 17 (7.5\%) were overt hypothyroid; about 5 (2.2\%) were hyperthyroid. 


\begin{tabular}{|c|c|c|c|c|c|c|}
\hline \multirow{2}{*}{$\begin{array}{c}\text { History of } \\
\text { Menstrual }\end{array}$} & Euthyroid & \multicolumn{2}{c|}{ Hypothyroid } & \multicolumn{2}{c|}{ Hyperthyroid } \\
\cline { 2 - 8 } & No. & $\%$ & No. & $\%$ & No. & $\%$ \\
\hline Acyclical & 39 & 22.03 & 6 & 13.3 & 0 & 0.0 \\
\hline Hypomenorrhoea & 1 & 0.6 & 1 & 2.2 & 2 & 40.0 \\
\hline Menorrhagia & 92 & 51.9 & 35 & 77.8 & 0 & 0.0 \\
\hline Metrorrhagia & 8 & 4.51 & 0 & 0.0 & 0 & 0.0 \\
\hline Oligomenorrhoea & 2 & 1.1 & 0 & 0.0 & 3 & 60.0 \\
\hline Polymenorrhagia & 16 & 9.03 & 2 & 4.5 & 0 & 0.0 \\
\hline Polymenorrhoea & 19 & 10.8 & 1 & 2.2 & 0 & 0.0 \\
\hline Table 3. Distribution of Pattern of Bleeding in Relation to \\
Thyroid Status \\
\hline
\end{tabular}

Among the euthyroid patients also, menorrhagia is most common. In patients with hypothyroidism, majority that is 35 out of 45 had menorrhagia. Next most common was acyclical bleeding. In patients with hyperthyroidism, majority that is 3 out of 2 had oligomenorrhoea and the next most common was hypomenorrhoea.

\begin{tabular}{|c|c|c|c|c|c|c|}
\hline \multirow{2}{*}{$\begin{array}{c}\text { Fractional } \\
\text { Curettage }\end{array}$} & \multicolumn{2}{|c|}{ Euthyroid } & \multicolumn{2}{c|}{ Hypothyroid } & \multicolumn{2}{c|}{ Hyperthyroid } \\
\cline { 2 - 7 } & No. & \% & No. & \% & No. & \% \\
\hline No FC & 37 & 20.90 & 5 & 11.11 & 2 & 40 \\
\hline Secretory & 41 & 23.16 & 12 & 26.66 & 0 & 0.0 \\
\hline Proliferative & 63 & 35.59 & 28 & 62.22 & 3 & 60 \\
\hline $\begin{array}{c}\text { Disordered } \\
\text { Proliferative }\end{array}$ & 36 & 20.33 & 0 & 0.0 & 0 & 0.0 \\
\hline
\end{tabular}

Table 4. Distribution of Thyroid Disorders in Patients with Abnormal Uterine Bleeding based on Fractional Curettage

Majority of the hypothyroid patients, that is 28 out of 45 had proliferative endometrium as the histological diagnosis on doing fractional curettage. Among the hyperthyroid patients, 3 out of 5 had proliferative endometrium. P value of this particular association was found to be 0.001 , which was statistically significant.

\begin{tabular}{|c|c|c|c|c|c|c|}
\hline \multirow{2}{*}{ Treatment } & \multicolumn{2}{|c|}{ Euthyroid } & \multicolumn{2}{c|}{ Hypothyroid } & \multicolumn{2}{c|}{ Hyperthyroid } \\
\cline { 2 - 8 } & No. & $\%$ & No. & $\%$ & Count & $\%$ \\
\hline No Drugs & 1 & 0.5 & 0 & 0.0 & 0 & 0.0 \\
\hline Tranexamic Acid & 122 & 68.9 & 9 & 20 & 0 & 0.0 \\
\hline Propylthiouracil & 0 & 0 & 0 & 0 & 5 & 100 \\
\hline Thyronorm & 0 & 0.0 & 7 & 15.55 & 0 & 0.0 \\
\hline $\begin{array}{c}\text { Tranexamic Acid } \\
\text { + Thyroxine }\end{array}$ & 0 & 0.0 & 29 & 64.4 & 0 & 0.0 \\
\hline $\begin{array}{c}\text { Tranexamic Acid + } \\
\text { Oral Contraceptive } \\
\text { Pills }\end{array}$ & 54 & 30.5 & 0 & 0.0 & 0 & 0.0 \\
\hline $\begin{array}{c}\text { Table 5. Distribution of Thyroid Disorders in Patients } \\
\text { with Abnormal Uterine Bleeding based on Treatment }\end{array}$ \\
\hline
\end{tabular}

Among the euthyroid patients, majority were given tranexamic acid alone.

Among the hypothyroid patients, majority were given tranexamic acid and thyroxine, and among hyperthyroid patients majority were given propylthiouracil.

\section{DISCUSSION}

Abnormal uterine bleeding is one of the most common gynaecologic problems that health care providers face, accounting for approximately $15 \%-20 \%$ of office visits and $25 \%$ of gynaecologic operations. ${ }^{8}$ It is estimated that a woman has 1 in 20 lifetime chance of consulting her primary physician because of menorrhagia. ${ }^{9}$ It has a direct impact on women's quality of life. Both hypothyroidism and hyperthyroidism may be associated with abnormal bleeding.
It has been stated that menorrhagia is more common in hypothyroidism or myxoedema, while anovulation or oligomenorrhoea is more common in hyperthyroidism. ${ }^{10}$ With the advent of modern hormonal assay techniques precise estimation of thyroid hormones in serum is possible in a rapid and reliable manner. And treatment of the underlying thyroid dysfunction by itself is found to significantly cause a reduction in menstrual complaints.

In this study, the majority of the study population belong to the age group of 41 - 50 years $(43.6 \%)$, which was comparable to the study done by N. Bhavani et al.

\begin{tabular}{|c|c|c|c|}
\hline Pattern of Bleeding & $\begin{array}{c}\text { \% (Present } \\
\text { Study) }\end{array}$ & $\begin{array}{c}\text { \% } \\
\text { (N.Bhavani) }\end{array}$ & $\begin{array}{c}\text { \% } \\
\text { (T.Sruthi) }\end{array}$ \\
\hline Menorrhagia & 55.9 & 54 & 45 \\
\hline Acyclical bleeding & 19.8 & 20.5 & 15 \\
\hline Hypomenorrhoea & 1.8 & 4 & - \\
\hline Oligomenorrhoea & 2.2 & 3 & 10 \\
\hline Polymenorrhoea & 7.9 & 3.5 & 17 \\
\hline Polymenorrhagia & 8.8 & 8.5 & 8 \\
\hline Metrorrhagia & 3.5 & 6.5 & 5 \\
\hline
\end{tabular}

Menorrhagia was the commonest presentation in other similar studies, that is N. Bhavani et al, N. Sharma et al and T. Sruthi et al. In all these studies, acyclical bleeding was the next commonest pattern of bleeding seen. So the results of the present study are comparable with the results of other studies. In a recent study conducted by Charusheela et al on 213 patients with DUB also, menorrhagia was the chief menstrual abnormality.

\begin{tabular}{|c|c|c|c|c|}
\hline $\begin{array}{c}\text { Thyroid } \\
\text { Status }\end{array}$ & $\begin{array}{c}\% \\
\text { (Present } \\
\text { Study) }\end{array}$ & $\begin{array}{c}\text { \% } \\
\text { (N.Bhavani } \\
\text { et al) }\end{array}$ & $\begin{array}{c}\% \\
\text { (M.Kanti } \\
\text { et al) }\end{array}$ & $\begin{array}{c}\% \\
\text { (T.Sruthi } \\
\text { et al) }\end{array}$ \\
\hline Euthyroid & 78 & 81 & 77 & 89 \\
\hline $\begin{array}{c}\text { Overt } \\
\text { Hypothyroid }\end{array}$ & 7.5 & 7.5 & 7 & 2 \\
\hline $\begin{array}{c}\text { Subclinical } \\
\text { Hypothyroid }\end{array}$ & 12.3 & 10 & 13 & 8 \\
\hline Hyperthyroid & 2.2 & 1.5 & 3 & 1 \\
\hline Table 7. Comparison of Thyroid Status between different \\
Studies \\
\hline
\end{tabular}

In all the above studies as given in the table, subclinical hypothyroidism was more common than overt and hyperthyroidism formed only a small percentage which was comparable with the present study. In studies carried out by Pahwa et al and $\mathrm{N}$. Sharma et al, prevalence of hypothyroidism in the study population was $22 \%$, which was comparable with the present study.

In the study by N. Sharma et al, 35.29\% hypothyroid women had menorrhagia and $20.58 \%$ had oligo/hypomenorrhoea, which was comparable with our study. In the study done by Pahwa et al also it was found that in cases of hypothyroidism, menorrhagia constituted $78.6 \%$ making it the most common complaint followed by 
polymenorrhoea. In the study by Charusheela et al, majority of hypothyroid patients had menorrhagia.

In the study by $\mathrm{N}$. Sharma et al, proliferative endometrium was seen in majority of the hypothyroid and hyperthyroid patients just like in the present study.

In the present study, majority of the overt hypothyroid patients who were treated with tranexamic acid and thyroxine were successful, which was very similar to the study carried out by Wilansky et al. Wilansky tested for thyroid releasing hormone in 67 women with menorrhagia. Of these, eight had been treated with thyroxine for an abnormal test result for thyroid releasing hormone and all considered their menstrual loss to have returned to normal.

The menorrhagia associated with hypothyroidism responds promptly to thyroid replacement. ${ }^{7}$ Thus, thyroid disorder should be considered as an important aetiological factor for menstrual abnormality and it is one of the conditions that is easily treatable.

\section{CONCLUSION}

Thyroid dysfunction should be considered as an important aetiological factor for menstrual abnormality. Biochemical estimation of T3, T4 and TSH should be made mandatory in abnormal uterine bleeding, especially if other structural pathologies and endometrial pathologies are ruled out. Evaluation of thyroid in abnormal uterine bleeding would also avoid unnecessary surgeries and exposure to hormones, as it is easily treated and thus improves quality of life.

\section{REFERENCES}

[1] Brenner PF. Differential diagnosis of abnormal uterine bleeding. Am J Obstet Gynaecol 1996;175(3 Pt 2): 766-9.
[2] Saheta A, Hariharan C, Sharma U, et al. Abnormal uterine bleeding. IOSR Journal of Dental and Medical Sciences 2014;13(11):63-7.

[3] Olive D, Palter S. Reproductive physiology. In: Berek JS. (eds). Berek and Novak's Gynaecology. 14th edn. Philadelphia: Lippincott Williams and Wilkins Company; 2002:161-86.

[4] Pitt-Rivers, Venetia R. The thyroid gland. In: PittRivers R, Trotter WR. (eds). Washington: Butterworth, 1964.

[5] Krassas GE, Pontikides N, Kaltsas T, et al. Disturbances of menstruation in hypothyroidism. Clin Endocrinol 1999;50(5):655-9.

[6] Krassas GE. Thyroid disease and female reproduction. Fertil Steril 2000;74(6):1063-70.

[7] Scott JC, Mussey E. Menstrual patterns in myxedema. Am J Obstet Gynaecol 1964;90:161-5.

[8] Awwad JT, Toth TL, Schiff I. Abnormal uterine bleeding in the perimenopause. Int $\mathrm{J}$ Fertil Menopausal Stud 1993;38(5):261-9.

[9] Hoffman BL. Abnormal uterine bleeding. In: Chapter 8, Schorge JO, Schaffer JI, Halvorson LM, (eds). Williams Gynaecology. Mc Graw Hill 2008:174-92.

[10] Joshi JV, Bhandarkar SD, Chadha M, et al. Menstrual irregularities and lactation failure may precede thyroid dysfunction or goitre. J Postgrad Med 1993;39(3):137-41. 